\title{
PENGARUH DAYA TARIK DAN WORD-OF-MOUTH TERHADAP KUNJUNGAN ULANG MELALUI KEPUASAN
}

\author{
Fitriandini Dwi Parastiwi, Naili Farida \\ Administrasi Bisnis, Universitas Diponegoro Semarang, Indonesia \\ Email: fitriandini03@gmail.com
}

\begin{abstract}
Tourism in Indonesia has been growing rapidly. Ketep Pass is one of the natural attractions in Magelang, Regency Central Java in which the number of visits during 2011 to 2015 hasbeen fluctuating. So that the goverment expect to increase visits to attractions Ketep Pass with satisfaction gained from seeing the sights and the positive impact (WOM). The purpose of this study was to identity the effect of attraction and word-of-mouth through satisfaction to re-visit the sights Ketep pass. This type of research is explanatory research, with data collection through questionnaires and interviews. The sampling technique used purposive sampling technique. The Sample was taken from 100 adult visitor respondents who have travelled to Ketep Pass. This study used quantitative analysis techniques. Quantitative analysis using validity, reliability test, the coefficient of correlation, simple and multiple regression analysis, the coefficient of determination, significance test ( $t$ test) in one direction, and Sobel test. The results of this research shown that there is a positive effect of natural attractions and word-of-mouth significantly on satisfaction, and satisfaction has a positive effect on return visits. Based on the analysis of Sobel test, known that the variable of natural attractions and word-of-mouth significant effect on satisfaction. Further variables significantly influence the satisfaction of repeat visits. Based on these results it is recommended to increase the repair and maintained the facilities to the tourist attractions as well as add a cultural event which could be an attraction for visitors to visit a tourist attraction Ketep Pass

Penelitian ini dilatar belakangi oleh pertumbuhan pariwisata yang berkembang pesat di Indonesia. Ketep Pass merupakan salah satu obyek wisata alam di Magelang-Jawa Tengah yang pada tahun 2011 hingga 2015 mengalami naik-turun kunjungan secara fluktuatif. Sehingga pengelola wisata berharap bisa meningkatkan kunjungan ke obyek wisata Ketep Pass dengan kepuasan yang didapat dari melihat pemandangan dan pengaruh positif (WOM). Tujuan penelitian ini adalah untuk mengetahui pengaruh daya tarik wisata dan word-of-mouth terhadap kunjungan ulang melalui kepuasan pada obyek wisata Ketep pass. Tipe penelitian ini adalah explanatory research, dengan teknik pengumpulan data melalui kuesioner dan wawancara. Teknik pengambilan sampel menggunakan teknik purposive sampling. Sampel berjumlah 100 responden yang merupakan pengunjung dewasa wisata Ketep Pass. Penelitian ini menggunakan teknik analisis kuantitatif. Analisis kuantitatif menggunakan uji validitas, uji reliabilitas, koefisien korelasi, analisis regresi sederhana dan berganda, koefisien determinasi, uji signifikansi (uji t) satu arah, dan uji sobel. Hasil penelitian menunjukkan bahwa terdapat pengaruh positif daya tarik wisata alam dan word-of-mouth secara signifikan terhadap kepuasan, dan kepuasan berpengaruh positif terhadap kunjungan ulang. Berdasarkan hasil analisis uji sobel, diketahui bahwa variabel daya tarik wisata alam dan word-ofmouth berpengaruh signifikan terhadap kepuasan. Selanjutnya variabel kepuasan berpengaruh signifikan terhadap kunjungan ulang. Berdasarkan hasil tersebut maka disarankan untuk meningkatkan perbaikan fasilitas dan perawatan terhadap tempat wisata serta menambah event budaya yang bisa menjadi daya tarik bagi pengunjung untuk berkunjung ke obyek wisata Ketep Pass.
\end{abstract}

Keywords

Natural Attractions (scenery), Word-of-mouth (positive effect), repeat visits, and visitor satisfaction Atraksi Alam (pemandangan), Dari Mulut ke Mulut (efek positif), kunjungan berulang, dan kepuasan pengunjung

\section{Pendahuluan}

Pariwisata merupakan bagian yang tidak terpisahkan dari kehidupan manusia, terutama menyangkut kegiatan sosial dan perekonomian. Diawali dari kegiatan yang semula hanya dinikmati oleh orang-orang yang relatif kaya pada awal abad ke-20, kini telah menjadi bagian dari hak azasi manusia. Hal ini terjadi tidak hanya di 
negara maju tetapi mulai dirasakan pula di negara berkembang.

Jawa Tengah merupakan salah satu tempat tujuan wisata bagi wisatawan mancanegara setelah Bali, dan biasanya merupakan satu paket wisata dengan tempat tujuan wisata Daerah Istimewa Yogyakarta. Daerah Jawa Tengah memiliki destinasi wisata yang cukup potensial dan cukup terkenal, selain itu daerah Jawa Tengah berdampingan dengan Daerah Istimewa Yogyakarta yang juga memiliki daya tarik destinasi wisata bagi para wisatawan mancanegara.

Kabupaten Magelang memiliki banyak sekali tempat pariwisata atau obyek pariwisata, ada 49 obyek wisata Kabupaten Magelang dan 11 Desa Wisata. Salah satu obyek wisata yang menarik adalah Ketep Pass. Ketep Pass adalah obyek wisata alam di puncak bukit sawangan yang terletak di pertengahan antara gunung Merapi dan gunung Merbabu. Secara administrasi tempat wisata alam yang mengususkan pada kegunungapian ini berada di Kabupaten Magelang, Jawa Tengah. Bukit Ketep Pass memiliki ketinggian sekitar 1200 meter dpl dan luas area sekitar 8000 meter persegi.

Kondisi kunjungan wisata di obyek wisata ketep pass yang fluktuatif menimbulkan upaya untuk dapat meningkatkan jumlah wisatawan di Ketep Pass, Magelang, Jawa Tengah, maka perlu dipahami kualitas tempat tujuan wisata (daya tarik) serta pengaruh cerita dari orang satu ke orang lainnya (WOM) dan pengaruhnya pada perilaku paska kunjungan yaitu kepuasan dan berkunjungan kembali sebagai bentuk komitmen atas kepuasan yang dirasakan wisatawan selama berwisata di Ketep Pass, Kabupaten Magelang, Jawa Tengah. Identifikasi kualitas tempat tujuan wisata merupakan usaha pemasaran berorientasi pelanggan untuk memahami kebutuhan dan keinginan wisatawan dalam melakukan perjalanan wisata. Pemasaran berorientasi pelanggan menjadi sesuatu yang sangat penting karena merupakan determinan terhadap perilaku pelanggan paska kunjungan.

\section{Kajian Teori}

\section{Daya Tarik Wisata Alam}

Menurut Basiya dan Rozak (2012), daya tarik tempat tujuan wisata merupakan motivasi utama bagi wisatawan untuk melakukan kunjungan wisata. Daya tarik wisata dikelompokan menjadi empat yaitu : Daya tarik wisata alam (natural attraction) yang meliputi pemandangan alam daratan,pemandangan alam lautan, pantai, iklimatau cuaca; Daya tarik wisata berupa arsitektur bangunan (building attraction) yang meliputi bangunan dan arsitektur bersejarah, bangunan dan arsitektur modern, arkeologi; Daya tarik wisata yang dikelola khusus (managed visitor attractions), yang meliputi tempat peninggalan kawasan industi seperti yang ada di Inggris, Theme Park di Amerika, Darling Harbour di Australia; Daya tarik wisata budaya (culturalattraction) yang meliputi teater, musium,tempat bersejaah, adat-istiadat, tempat-tempatreligius, peristiwa-peristiwa khususseperti festival dan drama bersejarah(pageants), dan heritage seperti warisanpeninggalan budaya.

\section{Word-of-mouth (WOM)}

Word-of-mouth adalah komunikasi interpersonal antara dua bahkan lebih individu seperti anggota kelompok referensi atau konsumen dan tenaga penjual (Assael,1995). Semua orang memiliki pengaruh atas pembelian terus menerus melalui suatu komunikasi. Rekomendasi dari mulut ke mulut merupakan salah satu faktor penting yang berpengaruh terhadap keputusan seseorang dalam membeli atau menggunakan suatu produk / jasa.

\section{Kepuasan Pengunjung}

Menurut Kotler dan Keller (2009: 138) Kepuasan adalah perasaan senang atau 
kecewa seseorangyang timbul karena membandingkan kinerja yang dipersepsikan produk (atau hasil) terhadap ekspektasi atau harapan mereka. Jika kinerja dibawah harapan, pelanggan tidak puas. Jika kinerja memenuhi harapan, pelanggan puas. Jika kinerja melebihi harapan, pelanggan amat puas atau senang.

\section{Kunjungan Ulang}

Menurut Miller, Glawter, and Primbram dalam Iman Khalid Abdul Qader (2008) mendefinisikan purchases intention adalah keadaan mental seseorang yang mencerminkan rencana untuk melakukan beberapa tindakan dalam jangka waktu tertentu. Definisi ini diasumsikan sebagai anteseden langsung dari perilaku.

Penerapannya dalam riset terhadap definisi purchasesintention adalah pelanggan akan melakukan tindakan pembelian kembali diwaktu yang akan datang sebagai respon langsung dari perilaku paska pembelian dalam jangka waktu tertentu.Sedangkan menurut Assael (1995), purchaseintention merupakan keinginan pelanggan untuk melakukan pembelian berulang diwaktu yang akan datang.

Model hipotesis yang digunakan dalam penelitian ini adalah sebagai berikut:

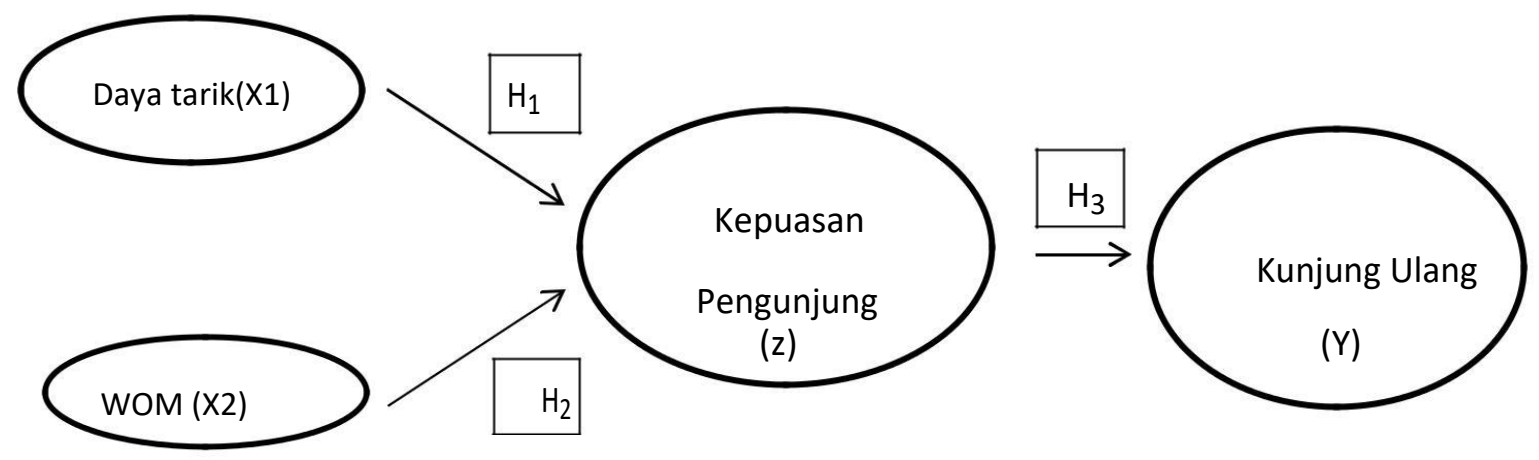

Gambar 1 Model Penelitian

\section{Hipotensis}

Adapun rumusan hipotesisnya adalah sebagai berikut:

$\mathrm{H}_{1}$ : Semakin tinggi Daya Tarik Wisata Alam, maka semakin tinggi Kepuasan Pengunjung

$\mathrm{H}_{2}$ : Semakin tinggi Word-of-mouth, maka semakin tinggi Kepuasan Pengunjung

$\mathrm{H}_{3}$ : Semakin tinggi Kepuasan pengunung, maka semankin tinggi keinginan untuk Berkunjung Ulang

\section{Metode Penelitian}

Penelitian yang akan penulis lakukan termasuk kedalam jenis penelitian Explanatory research. Penelitian explanatory adalah Penelitian yang bertujuan utuk menjelaskan hubungan dua atau lebih fenomena atau digunakan untuk menguji suatu teori atau hipotesis guna memperkuat atau bahkan menolak teori atau hipotesis suatu hasil penelitian yang telah ada.

Metode yang digunakan dalam teknik sampling yaitu Purposive sampling, dimana populasi minimal melakukan kunjungan sebanyak 2 kali berkunjungan selama 1 tahun terakhir. Jumlah sampel dalam penelitian ini adalah 100 orang / responden. Teknik pengambilan sampel yang digunakan adalah non probability sampling, tidak semua orang memiliki kesempatan yang sama untuk menjadi responden. Untuk menentukan siapa saja yang akan dijadikan responden dalam penelitian ini menggunakan aksidental. 
Menurut Sugiyono (2008), sampel aksidental adalah teknik penentuan responden berdasarkan siapa saja yang secara kebetulan dipandang cocok sebagai sumber data maka akan diberikan kuesioner.

Penelitian ini menggunakan teknik analisis kuantitatif. Analisis kuantitatif menggunakan bantuan program SPSS for Windows versi 17, dimulai dengan uji validitas dan uji reliabilitas, uji koefisien korelasi dan koefisien determinasi, kemudian uji regresi sederhana untuk mengetahui pengaruh masing-masing variabel independen $(\mathrm{X})$ terhadap variabel dependen (Y). Uji signifikansi (uji t) dilakukan untuk untuk menunjukkan seberapa jauh pengaruh satu variabel independen secara individual dalam menerangkan variasi variabel dependen (Ghozali, 2005), uji Sobel menggunakan Preacher's Tool, dan analisis variabel intervening menggunakan regresi 2 tahap. Regresi 2 tahap merupakan model regresi yang menunjukkan bahwa variabel intervening (Y1) di dalam penelitian ini dipengaruhi oleh dua variabel independen yakni X1 dan X2. Sementara itu variabel Y1 akan mempengaruhi variabel dependen Y2, model regresi seperti inilah yang disebut sebagai regresi dua tahap.

\section{Hasil}

\begin{tabular}{|c|c|c|c|c|}
\hline Input: & & Test statistic: & Std. Error: & $p$-value: \\
\hline a 0.289 & Sobel test: & 4.31870086 & 0.02375599 & 0.0000157 \\
\hline b 0.355 & Aroian test: & 4.29722494 & 0.02387471 & 0.00001729 \\
\hline$s_{a} 0.058$ & Goodman test: & 4.34050202 & 0.02363667 & 0.00001422 \\
\hline$s_{b} 0.041$ & Reset all & & Calculate & \\
\hline
\end{tabular}

Gambar 2 Uji Sobel word-of-mouth dan kepuasan terhadap kunjungan ulang

Berdasarkan uji Sobel dengan menggunakan Preacher's Tool di atas, dapat diketahui nilai tes $(\mathrm{t})$ statistik dari Sobel test, Aronian test, Godman's test, standar error, dan p-value nya. Dalam penelitian ini, hasil perhitungan Sobel yang digunakan adalah nilai Aronian test,

Dalam penelitian ini, hipotesis pertama yang menyatakan bahwa terdapat
Tabel 1 Hasil Uji Regresi daya tarik wisata dan word-of-mouth terhadap kepuasan

\begin{tabular}{ccccccc}
\hline \multirow{2}{*}{ Model } & \multicolumn{2}{c}{$\begin{array}{c}\text { Unstandardized } \\
\text { Coefficients }\end{array}$} & $\begin{array}{c}\text { Standardized } \\
\text { Coefficients }\end{array}$ & & \\
\cline { 2 - 4 } & $\mathrm{B}$ & Std. Error & Beta & & Sig. \\
\hline (Constant) & 17.048 & 1.737 & & 9.815 & .000 \\
$\mathrm{X} 1$ & .038 & .095 & .243 & .398 & .691 \\
$\mathrm{X}_{2}$ & .375 & .100 & .401 & & 3.757 & .000
\end{tabular}

Sumber: Data primer yang diolah, (2016)

Berdasarkan persamaan regresi pertama yaitu daya tarik wisata dan wordof-mouth terhadap kepuasan yang dilihat dapat tabel di atas, menunjukkan bahwa nilai koefisien regresi dari variabel daya tarik wisata bernilai positif yakni sebesar 0,243 dan nilai koefisien regresi dari variabel word-of-mouth juga bernilai positif yakni sebesar 0,401

Tabel 2 Hasil Uji Regresi kedua kepuasan terhadap kunjungan ulang

\begin{tabular}{|c|c|c|c|c|c|}
\hline \multirow{3}{*}{ Model } & $\begin{array}{r}\text { Unstand } \\
\text { Coeffi } \\
\end{array}$ & $\begin{array}{l}\text { ardized } \\
\text { cients }\end{array}$ & $\begin{array}{c}\text { Standardized } \\
\text { Coefficients }\end{array}$ & \multirow{3}{*}{$\mathrm{T}$} & \multirow{3}{*}{ Sig. } \\
\hline & \multicolumn{3}{|c|}{ Std. } & & \\
\hline & B & Error & Beta & & \\
\hline (Constant) & 6.134 & .904 & & 6.785 & .000 \\
\hline $\mathrm{Z}$ & .390 & .038 & .720 & 10.276 & .000 \\
\hline
\end{tabular}

Sumber: Data primer yang diolah, (2016)

Berdasarkan persamaan regresi kedua yang dapat dilihat pada tabel di atas, menunjukkan bahwa nilai koefisien regresi dari variabel kepuasan bernilai positif sebesar 0,720. Hal ini menunjukkan bahwa variabel kepuasan berhubungan positif dengan kunjungan ulang.

\section{Pembahasan}

Pada prinsipnya, penelitian ini bertujuan untuk mencari jawaban atas rumusan masalah yang telah dikemukakan pada bagian sebelumnya, dimana pada intinya untuk mengetahui pengaruh daya tarik wisata aalam dan word-of-mouth terhadap kunjungan ulang melalui kepuasan pengunjung sebagai variabel intervening.

pengaruh daya tarik wisata alam terhadap kepuasan telah terbukti. Hal ini dibuktikan 
melalui penelitian dengan hasil perhitungan nilai $\mathrm{t}$ hitung sebesar 3,007 yang lebih

memiliki hubungan yang positif dan signifikan terhadap kepuasan pengunjung. Hasil uji tersebut diperkuat dengan hasil perhitungan regresi yaitu sebesar 24,3\% dan sisa nya sebesar $75,7 \%$ atau 0,757 dipengaruhi oleh faktor lain, artinya adalah variabel kepuasan dapat dijelaskan oleh variabel daya tarik wisata alam sebesar $24,3 \%$ atau 0,243 dipengaruhi oleh daya tarik wisata alam, sehingga hipotesis satu yang berbunyi "terdapat pengaruh positif daya tarik wisata alam terhadap kepuasan" diterima. Hal ini sesuai dengan penelitian Basiya R dan Hasan A R (2012) yang menyatakan bahwa daya tarik wisata alam berpengaruh positif dan signifikan terhadap kepuasan pengunjung.

Hipotesis kedua yang menyatakan bahwa terdapat pengaruh word-of-mouth terhadap kepuasan telah terbukti. Hal ini dibuktikan melalui penelitian dengan hasil perhitungan nilai $\mathrm{t}$ hitung sebesar 5,015 yang lebih besar dari t tabel sebesar 1,660 yang menunjukkan bahwa word-of-mouth memiliki hubungan yang positif dan signifikan terhadap kepuasan. Hasil uji tersebut diperkuat dengan hasil perhitungan regresi yaitu sebesar 40,1\% atau 0,401 dan sisanya $59,9 \%$ atau 0,599 di pengaruhi oleh fakotr lain, artinya adalah variabel kepuasan dapat dijelaskan oleh variabel word-of-mouth sebesar $40,1 \%$ atau 0,401 , sehingga hipotesis dua yang berbunyi "terdapat pengaruh positif word-of-mouth terhadap kepuasan" diterima. Hal ini sesuai dengan penelitian yang dilakukan oleh Finnan Aditya Ajie Nugraha (2015), yang menunjukkan bahwa word-of-mouth berpengaruh signifikan terhadap kepuasan konsumen di obyek wisata Ketep Pass Magelang.

Hipotesis ketiga yang menyatakan bahwa terdapat pengaruh kepuasan terhadap kunjungan ulang telah terbukti. Hal ini dibuktikan melalui penelitian dengan hasil perhitungan nilai $\mathrm{t}$ hitung sebesar 10,276 yang lebih besar dari t tabel sebesar 1,660 yang menunjukkan bahwa besar dari $\mathrm{t}$ tabel sebesar 1,660 yang menunjukkan bahwa daya tarik wisata alam kepuasan memiliki hubungan yang positif dan signifikan terhadap kunjungan ulang. Hasil uji tersebut diperkuat dengan hasil perhitungan koefisien determinasi yaitu sebesar $72 \%$ atau 0,720 dan sisanya $28 \%$ atau 0,280 dipengaruhi oleh faktor lain, artinya adalah variabel kunjungan ulang dapat dijelaskan oleh variabel kepuasan pengunjung sebesar $72 \%$ atau 0,720, sehingga hipotesis tiga yang berbunyi "terdapat pengaruh positif kepuasan pengunjung terhadap kunjungan ulang" diterima. Hal ini juga sesuai dengan penelitian Yunantias, W., \& Kusumawardhani, A. (2015) yang menyatakan kepuasan memiliki efek positif secara signifikan langsung pada kunjungan ulang para wisatawan.

Berdasarkan pernyataan tersebut dapat diketahui bahwa variabel daya tarik wisata alam memiliki nilai koefisien regresi yang lebih tinggi dari variabel word-of mouth terhadap kepuasan $(0,243<0,401)$, yang berarti variabel word-of-mouth lebih mendominasi kepuasan. Hal ini dapat terjadi karena word-of-mouth yang disampaikan oleh seseorang akan menyenangkan untuk di dengar cara menyampaikannya, bisa mempengaruhi orang lain sehingga membuat orang lain ingin berkunjung dan membuktikan ceritanya. Sedangkan variabel daya tarik wisata alam meskipun berhubungan positif dengan kepuasan, namun pengaruhnya kurang mendominasi atas kepuasan pengunjung. Hal ini dikarenakan daya tarik wisata alam dirasa kurang membuat pengunjung merasa puas jika tidak adanya perkembangan yang signifikan dari obyek wisata Ketep Pass.

Berdasarkan hasil analisis regresi 2 tahap, dapat diketahui bahwa variabel kepuasan dapat menjadi variabel intervening dari daya tarik wisata alam dan word-of-mouthterhadap kunjungan ulang, karena variabel daya tarik wisata alam dan word-of-mouth memberikan pengaruh yang signifikan dan positif terhadap variabel 
kepuasan, dan variabel kepuasan memberikan pengaruh signifikan dan positif terhadap variabel kunjungan ulang. dapat menjadi obyek wisata yang bagus dan menarik pengunjung untuk berkunjung pada obyek wisata Ketep Pass. Dimana hal tersebut akan memberi pengaruh bagi tempat wisata dan memberikan manfaat yang besar bagi keberlangsungan obyek wisata Ketep Pass untuk meningkatkan profitabilitas tempat wisata.

\section{Kesimpulan}

1. Variabel daya tarik wisata alam mempunyai pengaruh positif terhadap kepuasan pengunjung obyek wisataKetep Pass ditunjukan dari nilai signifikansi sebesar 0,03 yang berada dibawah nilai 0,05 . Hal ini menunjukkan bahwa semakin bagus pemandangan alam di obyek wisataKetep Pass maka akan membuat pengunjung merasa puas.

2. Variabel word-of-mouth mempunyai pengaruh positif terhadap kepuasan pengunjung obyek wisataKetep Pass ditunjukan dari nilai signifikansi sebesar 0,00 yang berada dibawah niali 0,05 . Hal ini menunjukkan bahwa semakin banyak seseorang bercerita positif dan mempengaruhi orang tersebut untuk melihat pemandangan yang ada di obyek wisata Ketep Pass maka akan semakin membuat orang tersebut merasa puas karena mendengar cerita yang positif.

3. Variabel kepuasan pengunjung mempunyai pengaruh positif terhadap kunjungan ulang ke obyek wisataKetep Pass ditunjukan dari niali signifikansi sebesar 0,00 yang berada dibawah niali 0,05. Hal ini menunjukkan bahwa semakin puas pengunjung maka pengunjung akan kembali lagi dalam waktu dekat dengan melihat apakah ada perkembangan berdasarkan dari cerita orang lain setelah berkunjung di obyek wisata Ketep Pass.

4. Pengaruh daya tarik wisata alam terhadap kunjungan ulang melalui kepuasan pengunjung dibuktikan melalui hasil dari uji sobel dengan nilai $\mathrm{t}$
Apabila keempat variabel tersebut saling bersinergi maka obyek wisata Ketep Pass

statistik $(2,834)>\mathrm{t}$ tabel $(1,660)$, maka H0 ditolak dan Ha di terima, sehingga hipotesis 4 " terdapat pengaruh positif antara daya tarik wisata alam terhadap kunjungan ulang melalui kepuasan pengunjung" diterima. Nilai p-value $(0,0045)<$ taraf signifikansi $(0,05)$, maka pengaruh yang diberikan oleh variabel mediasi adalah signifikan.

5. Pengaruh word-of-mouth terhadap kunjungan ulang melalui kepuasan pengunjung dibuktikan melalui hasil dari uji sobel dengan Nilai t statistik (4,297> t tabel (1,660), maka H0 ditolak dan Ha di terima, sehingga hipotesis 5 “ terdapat pengaruh positif antara wordof-mouth terhadap kunjungan ulang melalui kepuasan pengunjung" diterima. Nilai p-value $(0,00001)<$ taraf signifikansi $(0,05)$, maka pengaruh yang diberikan oleh variabel mediasi adalah signifikan.

\section{Daftar Referensi}

A, Yoeti, Oka. 1980, Pemasaran Pariwisata, Penerbit Angkasa, Bandung.

A, Yoeti, Oka. 1997, Perencanaan dan Pengembangan Pariwisata, Jakarta : PT. Pradnya Paramita

Agung Nugroho, 2005. Strategi Jitu memilih Metode statistic Penelitian dengan SPSS, Andi Jogyakarta

Assael, Henry, 1995. Costumer Behavior And Marketing Action, Keat Publishing Company, Boston.

Assauri, Sofjan. 2004. "Manajemen Produksi dan Operasi", Lembaga Penerbit Fakultas Ekonomi Universitas Indonesia. Jakarta.

Buchari Alma. 2007, Manajemen Pemasaran \& Pemasaran Jasa. Bandung: CV.Alfabeta.

Basu Swastha dan Irawan, 2005, Manajemen Pemasaran Modern. Liberty. Yogyakarta. 
Buchari Alma, 2004, Manajemen Pemasaran dan Pemasaran Jasa, Edisi Revisi, Penerbit Alfabeta, Bandung.

: Reexamination and Extension, Journal of Marketing.

Cooper, Donald R, dan Emory William C (1997). Metode Penelitian Bisnis. Jakarta : Erlangga.

Dinas Pariwisata Kabupaten Magelang Tahun 2015

Finnan Aditya Ajie Nugraha. 2015. Pengaruh Word Of Mouth terhadap Keputusan Pembelian dan Kepuasan Konsumen (Studi pada Konsumen Kober Mie Setan jalan Simpang Soekarno-Hatta nomor 1-2 Malang)

Ferdinand, Agusty (2006). Metode Penelitian Manajemen. Semarang : Badan Penerbit Universitas Diponegoro.

Ghozali, Imam. (2005). Aplikasi Analisis Multivariate. Semarang : Badan Penerbit Universitas Diponegoro

Ghozali, Imam. (2009). Aplikasi Analisis Multivariate dengan Program SPSS. Badan Penerbit Universitas Diponegoro: Semarang.

Ghozali, Imam. 2011. “Aplikasi Analisis Multivariate Dengan Program SPSS".Semarang: Badan Penerbit Universitas Diponegoro.

Gremler dan Brown. 1997. Customer Relationship Marketing: A Strategic Imperative in the World of e.Business, Canada: John Wiley \& Sons Ltd.

Jan, M. T., Abdullah, K., \& Shafiq, A. (2013). The impact of customer satisfaction on word-of-mouth: conventional banks of Malaysia investigated. Journal

Kasali, R. 2003. Manajemen Public Relations. Grafiti, Jakarta.Kotler, P. and N Lee. 2005. Corporate Social Responsibility: Doing The Most Good for Your Company and Your Cause. John Wiley \& Sons Inc, New Jersey.
Cronin, J.Joseph Jr dan Steven Taylor, (1992), Measuring Service Quality

Kotler, Philip. 2000. Manajemen Pemasaran. Jilid 2.Jakarta. Bumi Aksara

Kottler dan Amstrong. 2001. Prinsipprinsip pemasaran. Jilid 1 Erlangga. Yogyakarta

Kotler, Philip. 2005. Manajamen Pemasaran, Jilid 1 dan 2. Jakarta: PT. Indeks Kelompok Gramedia

Kotler, Philip. 2009. Manajemen Pemasaran. Jakarta : Erlangga

Kozinets, R., Wojnicki, A.C., Wilner, S.J. and De Valck, K., 2010. Networked narratives: Understanding word-ofmouth marketing in online communities. Journal of Marketing, March.

Nyoman S. Pendit. (2002). Ilmu Pariwisata Sebuah Pengantar Perdana. Jakarta: PT. Pradnya Paramita.

Okello, M. M., \& Yerian, S. (2009). Tourist satisfaction in relation to attractions and implications for conservation in the protected areas of the Northern Circuit, Tanzania. Journal of Sustainable Tourism, 17(5), 605-625.

Pendit, I Nyoman, S. 1994. Ilmu Pariwisata Sebuah Pengantar Perdana. Jakarta: Pradnya Paramita.

Philip Kotler \& Kevin Lane Keller, 2009, Manajemen pemasaran, Edisi 13 Jilid 1. Jakarta.

Philip Kotler \& Kevin Lane Keller, 2009, Manajemen pemasaran, Edisi 13 Jilid 2. Jakarta

Rahmadevita, D.L. 2011. Pengaruh Reputasi Merek dan Komunitas Pelanggan terhadap Nilai Pelanggan, Word Of Mouth serta Keputusan Pembelian. Jurnal Profit. Volume 7 No. 1.

Ratna Acintya Putri. Pengaruh Citra Destinasi, Fasilitas Wisata Dan 
Experiential Marketing Terhadap Loyalitas Melalui Kepuasan(Studi Pada Pengunjung Domestik Taman Wisata Candi Borobudur)

Smith, S.L., 2014. Tourism analysis: A handbook. Routledge.

Soekadijo, R.G. (2000). Anatomi Pariwisata. Jakarta: PT Gramedia Pustaka Utama.

Sopyan. 2015. Analisi Pengaruh Daya Tarik Wisata dan Kualitas Pelayanan Terhadap Minat Berkunjungan Ulang Pengunjung dengan Kepuasan Pengunjung Sebagai Variabel Intervening (Studi pada Cagar Budaya Gedung Lawang Sewu). Semarang

Stanton, William J. 2003. Prinsip Pemasaran. Alih Bahasa oleh Sadu Sundaru. Jilid Satu. Edisi Kesepuluh. Jakarta : Erlangga.

Stephen F. Witt, (1994). Tourism Marketing and Managemen Handbook . British : Prentice Hall International
Sammeng, A.M. 2001. Cakrawala Pariwisata. Balai Pustaka. Jakarta

Sugiyono, (2008). Metode Penelitian Bisnis. Bandung : Alfabeta

Sugiyono, (2010). Metode Penelitian (Pendekatan Kuantitatif Kualitatif dan R\&D). Bandung : Alfabeta

Sunarto, SE.,MM. Perilaku Konsumen. Yogyakarta : Penerbit AMUS Yogyakarta dan Aditya Media Yogyakarta

Swastha, Basu dan Irawan. 2005, Manajemen Pemasaran Modern, Liberty, Yogyakarta.

Tjiptono, Fandy. (2008). Strategi Pemasaran (Edisi Tiga). Yogyakarta: Andi Yunantias, W., \&

Kusumawardhani, A. (2015). Analisis Pengaruh Kualitas Layanan dan Kepuasan Konsumen Terhadap Minat Kunjungan pada Obyek Wisata Pantai Widuri di Pemalang (Doctoral dissertation, Fakultas Ekonomika dan Bisnis). 